\title{
Penerapan Algoritma Viola-Jones Untuk Deteksi Masker Covid-19 Di Politeknik Perkeretaapian Indonesia Madiun
}

\author{
Teguh Arifianto ${ }^{* 1}$, Sunardi $^{2}$ \\ ${ }^{1,2}$ Teknologi Elektro Perkeretaapian Politeknik Perkeretaapian Indonesia Madiun \\ e-mail: ${ }^{1}{ }^{1}$ teguh@ppi.ac.id, ${ }^{2}$ sunardi@ppi.ac.id
}

\begin{abstract}
Abstrak
Algoritma Viola-Jones merupakan salah satu algoritma yang sering digunakan untuk mendeteksi wajah. Sistem pengenalan wajah manusia merupakan salah satu teknologi penting yang berfungsi sebagai sistem keamanan, sistem kontrol, dan lain-lain. Hal ini sesuai dengan tujuan penelitian yaitu untuk mengetahui penerapan algoritma Viola-Jones dalam mendeteksi penggunaan masker Covid-19 di Politeknik Perkeretaapian Indonesia Madiun. Metode penelitian yang digunakan yaitu menganalisa teknologi digital cetv dengan menangkap sebuah objek gambar diperlukan informasi kejelasan suatu objek. Dalam metode penilitian pendeteksi wajah menggunakan metode algoritma Viola-Jones. Hasil penelitian pada penelitian ini menunjukkan bahwa terdapat keberhasilan pendeteksian wajah sekitar pada jarak 1-2m dengan tingkat akurasi mencapai 95,5\% dan nilai error sebesar 4,5\% dalam mengenali wajah manusia.
\end{abstract}

Kata kunci- Algoritma Viola Jones, Deteksi Masker, Covid-19

\begin{abstract}
The Viola-Jones algorithm is one of the algorithms that is often used to detect faces. Human face recognition system is an important technology that functions as a security system, control system, and others. This is in accordance with the research objective, namely to determine the application of the Viola-Jones algorithm in detecting the use of Covid-19 masks at the Indonesian Railways Polytechnic Madiun. The method used is to analyze digital cctv technology by capturing an object that requires information on an object. In the face detection research method using the Viola-Jones algorithm method. The results of this study indicate that there is success in detecting surrounding faces at a distance of 1-2m with an accuracy rate of $95.5 \%$ and an error of $4.5 \%$ in recognizing human faces.
\end{abstract}

Keywords - Viola Jones Algorithm, Mask Detection, Covid-19

\section{PENDAHULUAN}

Saat ini, banyak sistem berkembang yang menggunakan fitur identifikasi wajah, salah satunya yaitu akses keamanan serta sistem kontrol [1]. Pengenalan wajah dimungkinkan dengan berbagai cara yang berbeda, salah satunya adalah memanfaatkan metode Viola-Jones, yaitu teknik yang menggabungkan support vector machines, algoritma boosting, dan cascade classifier [2]. Metode ini diterapkan pada citra digital dan mendapatkan citra wajah dengan berbagai posisi wajah yang berbeda. Metode viola jones dinilai relative lebih akurat, cepat, serta efisien. Metode viola jones merupakan metode yang paling banyak digunakan untuk mendeteksi citra, dimana pendeteksian wajah dilakukan dengan mengklasifikasikan sebuah citra yang sebelumnya telah ada di dalam data. Banyak peneliti yang telah mengembangkan deteksi 
wajah dan pengenalan citra, namun penelitian tersebut masih jauh dari kata sempurna dan hanya sedikit yang membahas pengenalan wajah berdasarkan posisi wajah

Metode algoritma viola jones memiliki 3 kontribusi berupa: kontribusi yang pertama adalah citra integral yaitu suatu citra dengan representasi citra baru, kontribus yang kedua dalam citra integral memungkinkan adanya evaluasi citra yang cepat serta menggunakan metode klasifikasi yang simple dan efektif ketika memilih fitur dalam Adaboost [3], kontribusi yang terakhir berupa menggabungkan classifier yang lebih kompleks secara berturut-turut dalam sebuah sruktur cascade (bertingkat) yang akan meningkatkan kecepatan dalam deteksi citra [4], [5]. Berdasarkan penelitian yang telah dilakukan sebelumnya untuk langkah penelitian selanjutnya adalah berupa penerapan algoritma viola jones untuk pendeteksi wajah.

Berdasarkan literature mengenai pentingnya melakukan deteksi wajah dan tantangan proses deteksi wajah maka perlu adanya pemilihan algoritma yang tepat [6]. Metode ViolaJones adalah teknik pengenalan objek dan memiliki tingkat akurat yang tinggi, yaitu sekitar 93,7\% dengan kecepatan beberapa kali lebih cepat daripada pengidentifikasi Rowley BalujaKanade dan 600 kali lebih cepat daripada indikator Schneiderman Kanade. Strategi ini diusulkan oleh Paul Viola dan Michael Jones pada tahun 2001.

Beberapa penelitian telah dilakukan untuk mendeteksi wajah, seperti yang telah dilakukan oleh [7] yang telah mengimplementasikan algoritma Viola Jones untuk mengklasifikasi warna kulit dan mendeteksi wajah. Viola Jones dikombinasikan dengan fitur ekstraksi warna RGB dan YCbCr. Hasil deteksi masih menunjukkan akurasi yang rendah dan masih terdapat banyak proses salah deteksi. Penelitian lainnya dalam proses deteksi wajah telah dilakukan oleh Zhao, dkk yang menggunakan AdaBoost untuk mengklasifikasi objek warna kulit dan sudah dapat digunakan untuk mendeteksi wajah dengan baik [8]. Menurut Wardoyo, deteksi wajah telah dilakukan menggunakan algoritma Principal Component Analysis (PCA)[9]. Proses pengenalan wajah membutuhkan wakyu yang cukup lama namun menghasilkan sensitiviotas $100 \%$. Pada beberapa objek masih terjadi kesalahan proses deteksi sehingga hanya menghasilkan 69,33\%. Penelitian lain yang dilakukan oleh Hardiyanto \& Anggun Sartika, melakukan kombinasi fitur warna pada algoritma Multi Layer Perceptron (MLP), sehingga nilai akurasi dan spesifitas menjadi lebih meningkat dibanding hanya menggunakan MLP saja [6].

\section{METODE PENELITIAN}

\subsection{Kajian Teori}

\section{Algoritma Viola-Jones}

Metode Viola-Jones dikemukakan oleh Paul Viola dan M.J Jones yang mengusulkan perpaduan tiga strategi untuk pendeteksi wajah [4]. Tiga kontribusi metode Viola-Jones adalah:

1. merupakan representasi citra baru yang disebut citra integral. citra integral memungkinkan penilaian komponen yang sangat tepat.

2. Metode pengelompokan dasar dan efisien dalam memilih fitur dengan adaboost.

3. Teknik yang menggabungkan classifier yang kompleks dalam Cascade clasifier. 


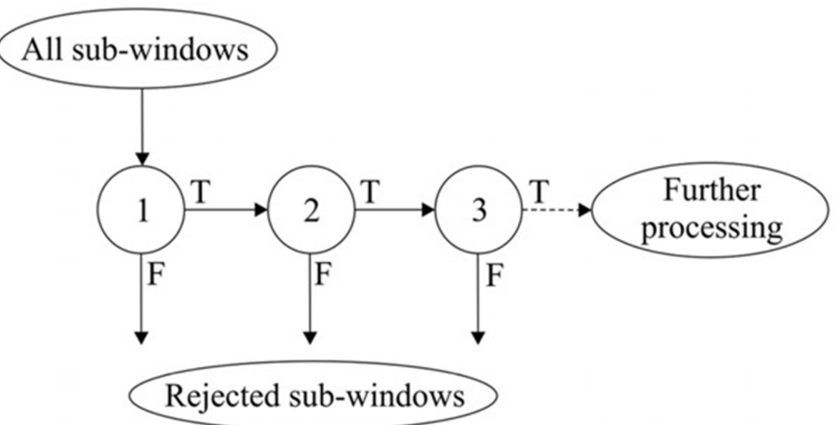

Gambar 1. Struktur Viola Jones

Viola-Jones menggunakan banyak pengklasifikasi yang berbeda, masing-masing melihat bagian gambar yang berbeda. Setiap classifier individu yang lemah (kurang akurat, menghasilkan lebih banyak false positive, dll) dari pada classifier akhir karena mengambil lebih sedikit informasi.

Deteksi wajah sering digunakan dan dimanfaatkan di berbagai perangkat teknologi digital pada zaman sekarang dengan memanfaatkan perkembangan teknologi komputer. Saat ini perkembangan aplikasi komersial yang sering menggunakan algoritma pendeteksi wajah maupun pengenalan wajah sangat pesat dalam perkembangannya. Maka dari itu, kita perlu belajar untuk mengikuti berkembangan teknologi agar mampu mengembangkan teknologi pengenalan wajah agar lebih optimal. Pengembangan harus didasarkan pada kecepatan dan akurasi sistem pendeteksi wajah yang tepat dan cepat [10]. Banyak dari sistem pendeteksi wajah tersebut menggunakan metode Viola Jones sebagai pendeteksi objek wajah manusia. ViolaJones menggunakan banyak pengklasifikasi yang berbeda, masing-masing melihat bagian gambar yang berbeda. Setiap classifier individu yang lemah (kurang akurat, menghasilkan lebih banyak false positive, dll) dari pada classifier akhir karena mengambil lebih sedikit informasi.

\section{Haar Like Feature}

Semua wajah manusia memiliki beberapa sifat yang serupa. Keteraturan ini dapat dicocokkan dengan menggunakan Fitur Haar [11]. Beberapa sifat yang umum pada wajah manusia:

a. Daerah pipi lbih terang daripada daerah mata yang lebih gelap.

b. Daerah mata lebih gelap daripada daerah hidung.

Komposisi sifat yang membentuk fitur wajah yang cocok:

a. Lokasi dan ukuran: mata, mulut, pangkal hidung.

b. Nilai: gradien berorientasi intensitas piksel.

Keempat fitur yang cocok dengan algoritma ini kemudian dicari dalam gambar wajah (ditampilkan di kanan). Fitur persegi panjang:

$$
\text { Nilai } \left.=\sum \text { (piksel di area hitam }\right)-\sum(\text { piksel di area putih })
$$

a. Tiga jenis: dua, tiga, empat persegi panjang, Viola \& Jones menggunakan fitur dua persegi panjang.

b. Misalnya: perbedaan kecerahan antara persegi panjang putih $\&$ hitam di area tertentu.

c. Setiap fitur terkait dengan lokasi khusus di jendela kecil.

Nilai Haar merupakan perhitungan selisih piksel antara daerah yang gelap dan terang sesuai persamaan (1) berikut: 
Dimana:

$$
F(\text { Haar })=\sum F \text { White }-\sum F \text { Black }
$$

$\mathrm{F}($ Haar $)=$ Nilai fitur total

$\sum \mathrm{F}$ White $=$ Nilai fitur objek terang

$\sum$ F Black $=$ Nilai fitur objek gelap

Kotak rectangular Haar dapat dihitung secara cepat dengan menggunakan Integral Image [12]. Pemrosessan dengan fungsi Haar dinilai masih kurang apabila menggunakan satu buah fungsi saja, sehingga perlu digunakan beberapa fungsi dengan tujuan menambah akurasi. Fungsi-fungsi Haar diolah dan diorganisir dalam classifier cascade [13].

\section{Cascade Classifier}

Cascade classifier merupakan metode klasifikasi yang bertingkat dimana setiap tingkatannya merupakan hasil dari tingkatan sebelumnya. Pada tingkatan cascade classifier pertama inputnya merupakan semua citra yang ada di sub_windows. Citra yang berhasil melewati tingkatan yang pertama maka selanjutnya akan menjadi inputan bagi classifie yang selanjutnya dan begitupun proses selanjutnya. Citra sub-windows yang berhasil meleati semua tingkatan classifier maka citra sub-windows tersebut akan menjadi citra wajah. Sedangkan citra yang tidak berhasil melewati tingkatan classifier maka akan tereliminasi dan dengn begitu proses pengidentifikasian akan lebih cepat.

Untuk meningkatkan efisiensi komputasi dan juga mengurangi tingkat false positive, Viola dan Jones menggunakan serangkaian klasifikasi yang semakin kompleks yang disebut cascade [14]. Sebuah jendela input dievaluasi pada klasifikasi pertama dari cascade dan jika class tersebut mengembalikan false maka perhitungan pada jendela itu berakhir dan detektor mengembalikan false. Jika classifier mengembalikan true maka jendela dilewatkan ke classifier berikutnya dalam cascade. Klasifikasi berikutnya mengevaluasi jendela dengan cara yang sama. Jika jendela melewati setiap classifier dengan semua mengembalikan true maka detektor mengembalikan true untuk jendela itu. Semakin banyak jendela yang terlihat seperti wajah, semakin banyak klasifikasi dievaluasi dan semakin lama waktu yang dibutuhkan untuk mengklasifikasikan jendela itu. Karena sebagian besar jendela dalam gambar tidak terlihat seperti wajah, sebagian besar dengan cepat dibuang sebagai bukan wajah.

\section{Deteksi Wajah}

Saat ini banyak penelitian yang teah menggunakan citra wajah. Dalam face recognition pendteksi wajah merupakan langkah awal penelitian [15]. Pendeteksi wajah saat ini tengah hangat dibicarakan dan diangkat sebagai penelitian oleh para peneliti di bidang computer vision serta patern rcognition[16]. Sedangkan menurut Sheng (2012) dalam mendeteksi wajah juga terdapat beberapa kesulitan diantaranya[17]:

1. Membedakan wajah dan non wajah yang ada pada citra, serta menilai gambar wajah yang ada pada citra.

2. Wajah yang memiliki rincian yang rumit misalnya kulit wajah dan perbedaan individual yang cukup jelas, bahkan ekspresi yang berbeda, gerak tubuh, hal tersebut akan membuat hasil deteksi wajah yang berbeda.

3. Gaya rambut yang beda, serta pemakaian kacamata atau benda-benda lain.

4. Perbedaan dalam sudut pengambilan gambar, serta ekspresi wajah.

Salah satu peneliti yang telah menggnakan pendeteksi wajah dalam penelitiannya adalah Shemshaki \& Amjadifard (2011), yang memakai Fuzzy Granulation dan Skin Color Segmentation dalam penelitiannya untuk mendeteksi wajah [18]. Penelitian selanjutnya adalah dengan menggunakan Algoritma Support Vector Machine (SVM) yang dilakukan oleh Marami 
\& Tefas (2010)[19]. Penelitian yang dilakukan oleh Feraud et al., (2001) Deteksi wajah berbasis Algoritma Neural Network [20]. Menurut Wang \& Abdel-dayem (2012) algoritma yang menjadi standart de facto dalam pendeteksi wajah adalah Algoritma Viola Jones [21].

\subsection{Metode Penelitian}

Pada metode penelitan kali ini, peneliti menganalisa teknologi digital CCTV. Bagaimana proses penangkapan objek gambar yang terekam di dalam perangkat tersebut. Dengan pengamatan ini kami menganalisis bahwa untuk menangkap sebuah objek gambar diperlukan informasi kejelasan suatu objek. Dalam metode penilitian pendeteksi wajah kali ini kami menggunakan berbagai macam cara untuk merekam gambar wajah individu dari penelitian tersebut untuk menangkap dan mengenali objek gambar wajah individu, kamera memerlukan informasi pengenalan wajah yaitu mata, hidung, dan mulut. Hal ini untuk pengenalan pendeteksi wajah kami menggunakan metode algoritma Viola-Jones.

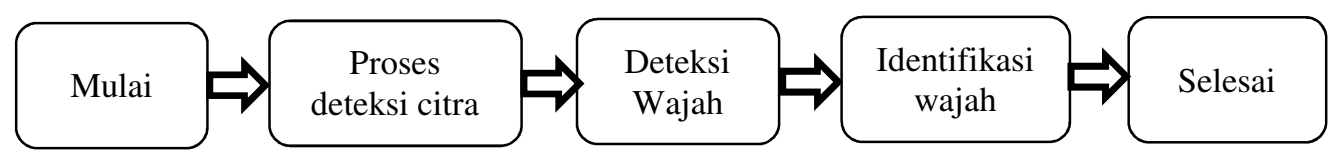

\section{HASIL DAN PEMBAHASAN}

\subsection{Analisis Sistem}

Framework ini dibuat menggunakan bahasa pemrograman Python menggunakan library OpenCV, dengan inputannya adalah gambar dan vidio, gambar diperoleh dari file citra latih sedangkan rekaman diambil secara langsung menggunakan webcam dan kemudian diolah setiap framenya. citra latih adalah gambar yang telah dirangkai dengan jumlah 635 citra dengan objek menggunakan masker.sedangkan citra masker yang diklasifikasikan berjumlah 80 citra, untuk selanjutnya dalam klasifikasi digunakan software cascade training GUI sehingga akan menghasilkan file yang memiliki format .xml yang isinya berupa fitur dari citra masker.didalam tahap akhir akan dilakukan pencocokan citra dan akan dibedakan antara wajah yang menggunakan masker dan tidak menggunakan masker, jika wajah yang dideteksi tidak menggunakan masker maka akan mucul fitur peringatan berupa "Mohon kenakan masker Anda!", yang berupa audio yang telah disediakan sebelumnya dan akan langsung memotret wajah.

\subsection{Citra RGB}

Proses pertama berupa memasukkan citra wajah yang akan diuji, dalam penelitian ini penulis penggunakan citra RGB. Citra RGB atau biasa disebut gambar berwarna adalah jenis citra yang memiliki kumpualan piksel warna (Biru, Hijau, Merah). Dan memiliki nilai (range) dari 0 (hitam) sampai 255 (putih). 


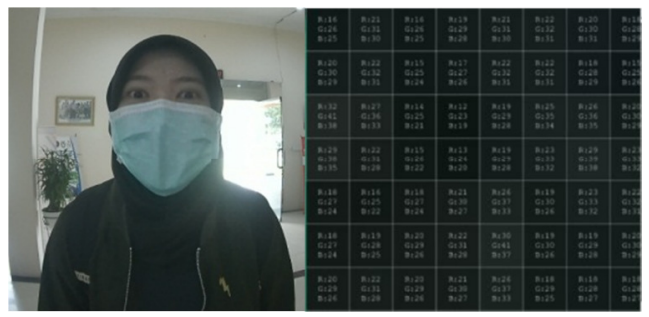

Gambar 1. Citra RGB

\subsection{Konversi Citra RGB ke Gray}

citra skala keabuan atau biasa disebut citra grayscala merupakan citra yang hanya memiliki kumpulan piksel 2 warna yaitu putih(white) dan hitam( black). Dan memiliki nilai (range) dari 0 (hitam) hingga 255 (putih).dapat mengubah citra dari RGB ke Grayscale dengan cara membagi total nilai pada piksel dengan 3 .

$$
\text { Gray }=\frac{(R+G+B)}{3}
$$

Atau bisa juga menggunakan persamaan 1:

$$
\text { Gray }=\frac{(0,299 \times R+0,587 \times G+0,114 \times B)}{3}
$$

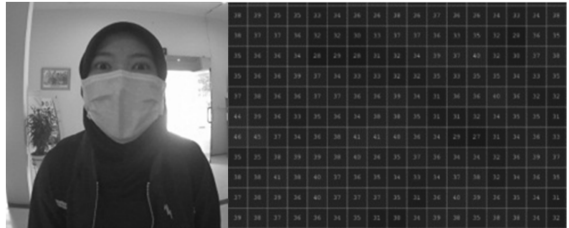

Gambar 2. Citra Grayscale

\subsection{Deteksi Masker}

Dekteksi masker merupakan pendeteksi apakah wajah tersebut memakai masker atau tidak. Sebagai contohnya, penulis menggunakan citra RGB yang ada pada gambar 1. Dan diubah menjadi citra grayscale seperti yang ada pada gambar 2 .

Deteksi masker menggunakan library openCV yang telah memiliki banyak fitur pengklasifikasi. Dapat juga digunakan untuk mengklasifikasikan wajah secara langsung untuk mendeteksi posisi wajah. Dalam klasifikasi ini digunakan modul detectMultiScale. Fngsi tersebut akan mengembalikan persegi panjang dengn koordinat $(\mathrm{x}, \mathrm{y}, \mathrm{w}, \mathrm{h}) \mathrm{dn}$ akan mengelilingi bagian yang diinginkan.parameter tersebut berupa: gambar.

Scalefactor $=$ yaitu value yang akan menunjukkan ukuran gambar dan dikurangi rasio

minNeighbours $=$ menentukan seberapa banyak neighbours yang akan dimiliki setiap persegi panjang.

minSize $=$ ukuran minimum objek.

Pada penelitian ini, digunakan nilai berbeda untuk ScaleFactor dan minNeighbours.

mask
masker.detectMultiScale(gray, $1.2,4)$




\subsection{Deteksi Jumlah Manusia}

Dalam mendeteksi jumlah manusia dengan tingak akurasi sistem maka digunakan metode Histogram of Oriented Gradient (HOG). Dalam metode tersebut akan dilakukan pengujian untuk mengetahui jarak minimum dan maksimum dalam deteksi jumlh manusia.

\begin{tabular}{|l|l|l|}
\hline Sampel & Jarak (m) & Keterangan \\
\hline & $2 \mathrm{~m}$ & \\
\hline
\end{tabular}

\subsection{Deteksi Pengenalan Wajah}

Dalam melakukan deteksi pengenalan wajah untuk mengetahui tingkat akurasinya maka dilakukan pengujian untuk mengetahui jarak antara kamera dengan wajah. pengujian tesebut dilakuakn untuk mengetahui jarak minimum serta maksimum jangkauan dalam mendeteksi pengenalan wajah.

\begin{tabular}{|l|l|l|}
\hline Sampel & Jarak (m) & Keterangan \\
\hline & $1 \mathrm{~m}$ & Terdeteksi \\
\hline & & \\
\hline \\
\hline
\end{tabular}




\subsection{Pembahasan}

Penelitan ini dilakukan pada siang hari saat cahaya matahari cukup dan dengan ketinggian kamera $150 \mathrm{~cm}$. Pengujian ini dilakuakn untuk mengetahui akursi jarak pendeteksi dan akurasi sistem. Dalam melakukan pengambilan video akan diambil secara real time.

Untuk mendeteksi tingkat akurasi sistem pentedeksi wajah manusia maka digunakan rumus sebagai berkut:

$$
\text { Akurasi }=\frac{\text { Jumlah Data Benar }}{\text { Jumlah Keseluruhan Data }}
$$

Jumlah Data Benar $=$ Jumlah obyek terdeteksi dengan benar

Keseluruhan Data $=$ Jumlahttotal sampel pengujian

\subsection{Deteksi Jumlah Manusia}

Hasil pendeteksi jumlah manusia yang dilakukan dengan jarak 2 meter sampai dengan 13 meter. Pada jarak 2 - 3.5 meter akurasi sistem masih belom mamapu unutk mendeteksi jumlah manusia. Sedangkan saat berada pada jarak 5 meter sampai 11 meter sistem telah mampu mendeteksi jumlah manusia sehingga akan muncul kerteangan berupa " jumlah orang = 1 "disudut atas hasi vidio. pada jarak 13 meter sistem sudah tidak dapat mendeteksi adanya manusia sehingga "jumlah orang $=0$ " muncul pada hasil video. Ini terjadi karena ukuran piksel objek terlalu besar jika jaraknya di bawah 3,5 m. Selain itu, terlalu kecil jika lebih dari 11 meter..

Dalam penelitian ini digunakan 45 sampel. Pengujian dilakukan dari 1 hingga 10 orang. Hasil pengujian ini menunjukkan ada 43 yang tereteksi dan 2 yang tidak terdeteksi, ini karena situasi acak dari objek manusia sehingga ada objek manusia yang tidak terdeteksi oleh sistem, untuk menemukan nilai akurasi menggunakan rumus (1).

$$
\begin{aligned}
\text { Akurasi } & =\frac{43}{45} \times 100 \% \\
& =95,55 \% \\
& \text { Dari hasil perhitungan menunjukkan tingkat akurasi deteksi jumlah manusia sebesar }
\end{aligned}
$$

\subsection{Deteksi Pengenalan Wajah}

Dalam mendeteksi akurasi sistem pengenalan wajah dilakukn 2 percobaan yang berbeda dengan wajah yang sama namun jarak yang berbeda, . untuk jarak $1-3$ objek wajah dapat dibedakan dan sistem juga siap untuk mengenali tanda nama seperti yang ditunjukkan oleh dataset yang telah disimpan. Dijarak 4 meter sistem dapat mendeteksi adanya wajah namun sistem belum dapat mengenali adanya dataset sehingga muncul keterangan "unknow" pada wakah yang terdeteksi. Sedangakan pada jarak 5 meter sistem tidak mendeteksi adanya wajah serta name tag shingga tidak ada keterangan apapun. Alasan wajah tidak tedeteksi ketika lebih dari jarak 3 meter adalah karena ukuran piksel terlalu kecil sehingga tingkat keakuratan menurun dan tidak dapat mengenali sesuai dengan data set yang ada.

Sehubungan dengan pengujian yang berbeda yang dilakukan untuk menentukan jarak antara orang yang akan dibedakan, ini menunjukkan bahwa semakin jauh objek dari kamera dan semakin dekat antara dua objek yang berdekatan, akan sulit untuk mengidentifikasi dua objek sehingga sistemnya hanya siap untuk mengenali satu objek manusia.

Pada pengujian ini dilakukan dengan mendeteksi wajah berurutan dari satu wajah sampai 5 wajah. Pada pengujian ini dilakukan pengenalan wajah secara berurutan dari satu wajah hingga 5 wajah. jumlah yang dikenali dari keseluruhan pengujian adalah 4 wajah sedangkan jumlah yang tidak akurat atau tidak terdeteksi seperti yang ditunjukkan oleh nama dataset adalah 1 wajah. Ketepatan pengenalan wajah yang lemah ini disebabkan oleh 
keterbatasan pada perangkat raspberry sehingga ketika mengidentifikasi beberapa wajah, video akan mengalami penundaan. Sehingga mencegah proses pengenalan wajah namun framework dapat mengidentifikasi semua wajah dari satu wajah hingga 5 wajah secara bersamaan. Untuk mengetahui nilai ketepatan menggunakan persamaan (1)

A. Akurasi label sesuai dataset

$$
\begin{aligned}
\text { Akurasi } & =\frac{6}{10} \times 100 \% \\
& =60 \%
\end{aligned}
$$

Hasil dari tingkat akurasi sistem pengenalan wajah dengan label nama sesuai data set adalah sebesar $60 \%$

B. Akurasi pendeteksian wajah

$$
\begin{aligned}
\text { Akurasi } & =\frac{10}{10} \times 100 \% \\
& =100 \%
\end{aligned}
$$

Sedangkan mendeteksi wajah tanpa name tag adalah sebesar $100 \%$

\subsection{Pengujian Dengan Data Citra Gambar}

Dilakukan juga pengujian secara manual yaitu dengan memasukkan citra satu persatu. maka akan didaptkan hasil seperti pada tabel berikut.

\begin{tabular}{|c|c|c|c|c|c|}
\hline No. & Jumlah & Jenis Kelamin & Warna & Jenis & $\begin{array}{c}\text { Jumlah } \\
\text { Terdeteksi }\end{array}$ \\
\hline 1. & 10 & Pria & Biru & Kain & 10 \\
\hline 2. & 10 & Pria & Biru muda & Bedah & 8 \\
\hline 3. & 10 & Pria & Putih & N95 & 10 \\
\hline 4. & 5 & Pria & Putih & Kain & 5 \\
\hline 5. & 5 & Wanita & Putih & Kain & 3 \\
\hline 6. & 3 & Wanita & Hitam & Kain & 2 \\
\hline
\end{tabular}

Dari tabel diatas dapat diketahui data uji atau sampel sebanyak 43 citra, citra masker yang dapat terdeteksi adalah sebanyak 38 citra (positif). Dan dilakuka perhitungan dengan persamaan (1) dan didapatkan hasil keakuratan sebagai berikut.

$$
\text { Akurasi }=\frac{38}{48} \times 100 \%=79,1 \%
$$

\section{KESIMPULAN}

Berdasarkan penelitain yang telah dilakukn maka didapatkan kesimpuan Pada pengujia jumlah deteksi manusiakeberhasilan system berapda pada jarak 5-11 meter dikarenakan ukuran piksel yag terlalu besar jika dekat dan teralu kecil jika jauh. Serta memilki tingkat keakuratan sistem sebesar $95,5 \%$ dan nilai error sebesar $4,5 \%$ dalam mendeteksi jumlahmanusia. Pada pendeteksi wajah sistem dapat meneteksi wajah secara akurat pada jarak $1-2$ meter. Hasil pengujian juga menunjukkan tingkat akurasi sebesar $60 \%$ dan memiliki nilai error sebesar $40 \%$ dalam mengenali wajah manusia serta name tag. Sedangkan dalam mendeteksi wajah tanpa name tag didapatkan akurasi 
sebesar $100 \%$ dan error 0\%. Sistem juga sulit untuk membedakan wajah yang tersimpan dalam data set dengan objek yang mirip.

\section{DAFTAR PUSTAKA}

[1] A. Zein, 2019, "Pengenalan Wajah Berdasarkan Fitur Wajah Menggunakan Opencv Python dan Deeplearning,” J. Ilmu Komput. JIK,.

[2] J. M. Al-Tuwaijari and S. A. Shaker, 2020, "Face Detection System Based Viola-Jones Algorithm,” doi: 10.1109/IEC49899.2020.9122927.

[3] Y. Freund and R. E. Schapire, 1997, "A Decision-Theoretic Generalization of On-Line Learning and an Application to Boosting," J. Comput. Syst. Sci., doi: 10.1006/jcss.1997.1504.

[4] P. Viola and M. J. Jones, 2004, "Robust Real-Time Face Detection," Int. J. Comput. Vis., doi: 10.1023/B:VISI.0000013087.49260.fb.

[5] P. Viola and M. Jones, 2001, "Rapid Object Detection Using A Boosted Cascade of Simple Features,” doi: 10.1109/cvpr.2001.990517.

[6] D. Hardiyanto and D. Anggun Sartika, 2018, "Optimalisasi Metode Deteksi Wajah berbasis Pengolahan Citra Untuk Aplikasi Identifikasi Wajah pada Presensi Digital,"

Setrum Sist. Kendali-Tenaga-Elektronika-Telekomunikasi-Komputer, doi: 10.36055/setrum.v7i1.3367.

[7] J. Kovač, P. Peer, and F. Solina, 2003, "Illumination Independent Color-Based Face Detection," doi: 10.1109/ISPA.2003.1296950.

[8] Q. Zhao, D. Zhang, and H. Lu, 2005, "Supervised LLE in ICA Space For Facial Expression Recognition,” doi: 10.1109/icnnb.2005.1615010.

[9] S. Wardoyo, R. Wiryadinata, and R. Sagita, 2015 "Sistem Presensi Berbasis Agoritma Eigenface Dengan Metode Principal Component Analysis," Setrum,.

[10] P. A. Jusia, 2017 "Face Recognition Menggunakan Metode Algoritma Viola Jones Dalam Penerapan Computer Vision,” J. Process., Vol. 11(1), pp. 663-675,.

[11] J. Kaur, A. Sharma, and A. Cse, 2017. "Performance Analysis of Face Detection by Using Viola-Jones Algorithm,"

[12] F. Utaminingrum, R. Primaswara, and Y. Arum Sari, 2017, "Image Processing For Rapidly Eye Detection Based On Robust Haar Sliding Window,” Int. J. Electr. Comput. Eng., doi: 10.11591/ijece.v7i2.pp823-830.

[13] C. Li, Z. Qi, N. Jia, and J. Wu, 2017, "Human Face Detection Algorithm Via Haar Cascade Classifier Combined With Three Additional Classifiers," doi: 10.1109/ICEMI.2017.8265863. 
[14] R. Wahyusari and B. Haryoko, 2014. "Penerapan Algoritma Viola Jones untuk Deteksi Wajah," J. Maj. Ilm. STTR Cepu,

[15] M. D. T. Shongyan, 2010, “Improved Adaboost," Int. Conf. Meas. Technol. Mechatronics Autom., pp. 434-437,.

[16] C. Pu-chun, 2010, "Face Detection Method Based on Skin Color and AdaBoost Algorithm,” Int. Conf. Comput. Informatics Sci., pp. 144-147,.

[17] G. Sheng, 2012, "Face Detection in Complex Background Using AdaBoost Algorithm," Sixth Int. Conf. Internet Comput. Sci. Eng., pp. 148-154.

[18] M. Shemshaki and R. Amjadifard, 2011, "Face Detection Based On Fuzzy Granulation and Skin Color Segmentation," doi: 10.1109/CICSyN.2011.55.

[19] E. Marami and A. Tefas, 2010, “Optimization and Support Vector Machines," Hell. Conf. Artif. Intell., Vol. 24843, No. Springer-Verlag Berlin Heidelberg, pp. 369-374.

[20] R. Féraud, O. J. Bernier, J. E. Viallet, and M. Collobert, 2001, "A Fast and Accurate Face Detector Based On Neural Networks," IEEE Trans. Pattern Anal. Mach. Intell., doi: $10.1109 / 34.899945$.

[21] S. Wang and A. Abdel-dayem, 2012, "Improved Viola-Jones Face Detector," Int. Conf. Commun. Inf. Technol., Vol. 1, pp. 123-128, 